\title{
NOTE
}

\section{White spot syndrome virus (WSSV) in cultured Penaeus monodon in the Philippines}

\author{
Fe O. Magbanua ${ }^{1}$, Karlo T. Natividad ${ }^{1}$, Veronica P. Migo ${ }^{1}$, Catalino G. Alfafara ${ }^{1}$, \\ Florian O. de la Peña ${ }^{2}$, Rolando O. Miranda ${ }^{2}$, Juan D. Albaladejo ${ }^{2}$, \\ E. Cesar B. Nadala Jr ${ }^{3}$, Philip C. Loh ${ }^{4}$, Lourdes Mahilum-Tapay ${ }^{1, *}$

\begin{abstract}
${ }^{1}$ National Institute of Molecular Biology and Biotechnology (BIOTECH), University of the Philippines-Los Baños, College, Laguna 4031, Philippines

${ }^{2}$ Bureau of Fisheries and Aquatic Resources, Department of Agriculture, Quezon City 1001, Philippines

${ }^{3}$ Deptartment of Haematology, University of Cambridge, EABC Site, Long Road, Cambridge CB2 2PT, United Kingdom

${ }^{4}$ Virus Laboratory, Department of Microbiology, University of Hawaii, Honolulu, Hawaii 96822, USA
\end{abstract}

\begin{abstract}
The prevalence and geographic distribution of white spot syndrome virus (WSSV) infection among cultured penaeid shrimp in the Philippines was determined from January to May, 1999, using PCR (polymerase chain reaction) protocol and Western blot assays. A total of 71 samples consisting of 18 post-larvae (PL) and 53 juvenile/adult shrimp samples (56 to 150 days-of-culture, DOC) were screened for WSSV. Of the 71 samples tested, 51 (72\%) were found positive for WSSV by PCR: $61 \%$ (31/51) after 1-step PCR and $39 \%$ (20/51) after 2-step, non-nested PCR. Of the PL and juvenile/adult shrimp samples tested, 50 and $79 \%$ were positive for WSSV, respectively. By Western blot, only 6 of the 51 $(12 \%)$ PCR-positive samples tested positive for WSSV. Of the 20 samples negative for WSSV by PCR, all tested negative for WSSV by Western blot assay. This is the first report of the occurrence of WSSV in the Philippines.
\end{abstract}

KEY WORDS: White spot syndrome virus · Polymerase chain reaction - Western blot

Resale or republication not permitted without written consent of the publisher

In the last decade, disease outbreaks in cultured penaeid shrimp have wreaked havoc worldwide, especially in Asian countries, including the Philippines. Although the outbreaks in the Philippines have been attributed mainly to luminous vibriosis (Lavilla-Pitogo et al. 1990), the possible role of viruses could not be totally ruled out. After the reports of Natividad (1991) and Lightner et al. (1992), no studies on shrimp viruses were made in the Philippines until 1998, when Albaladejo et al. (1998) reported the presence of yellowhead virus (YHV) in some cultivated Penaeus mon-

*Corresponding author. E-mail: lmt@laguna.net odon. In 1999, Belak and associates (Belak et al. 1999) reported the absence of white spot syndrome virus (WSSV) by polymerase chain reaction (PCR) assay in wild spawners obtained from Palawan, Quezon, Capiz and Negros Occidental. To date, there is a lack of information on the true status of shrimp viral diseases, such as WSSV, in the Philippines and this may consequently pose a great threat to the growth of the shrimp aquaculture industry. It is therefore imperative that screening and monitoring programs initiated by the Philippines' Bureau of Fisheries and Aquatic Resources, Department of Agriculture, be continued in order to determine the prevalence of some of the highly pathogenic shrimp viruses emerging in the farms and hatcheries in the Philippines.

Two important viral pathogens, YHV and WSSV, have been reported in Asia and elsewhere (Boonyaratpalin et al. 1993, Nakano et al. 1994, Chou et al. 1995, Wang et al. 1995, Wongteerasupaya et al. 1995, Durand et al. 1996, Lo et al. 1996a, Lu et al. 1997, Wang et al. 1997, Hameed et al. 1998), and several nucleic acid and/or immunologically based detection protocols have been developed for them (Kimura et al. 1996, Lo et al. 1996b, Nadala et al. 1997, Hameed et al. 1998, Kim et al. 1998, Tapay et al. 1999). For example, a combined SDS-PAGE/Western blot/nitrocellulose-enzyme immunoassay method for the early detection of both YHV and WSSV has been used to demonstrate the presence of specific viral proteins in the hemolymph of experimentally infected animals as early as $43 \mathrm{~h}$ post infection (Nadala et al. 1997). Also, a diagnostic probe for WSSV was reported by Durand et al. (1996) based 
on EcoRI-digested fragments of the WSSV genome that were cloned and labeled with DIG-11-dUTP. With respect to PCR assays, Kim et al. (1998) developed a PCR procedure for WSSV that is able to detect $1 \mathrm{pg}$ of WSSV DNA after 30 cycles using a template comprising of total nucleic acid extracted either from diseased shrimp or from hatchery shrimp with no signs of viral infection. Lo et al. (1996b) also developed PCR primers and nucleic acid probes for diagnosis of WSSV. In addition, Tapay et al. (1999) developed a PCR protocol that can detect 4 different geographic isolates of WSSV. These PCR protocols can detect low levels of WSSV in the hemolymph of broodstocks and so do not require animal sacrifice.

In this paper, employing both the PCR and Western blot viral detection protocols, we report, for the first time, the occurrence of WSSV in the Philippines.

Materials and methods. A total of 71 samples from various geographic locations in the Philippines (Fig. 1) collected between January and May 1999 were analyzed for WSSV by Western blot and PCR assays. The samples, which consisted of 18 post-larvae (PL) and 53 juvenile/adult shrimp, were obtained from shrimp farms either with reported cases of mortality or solely for monitoring purposes. Samples were obtained from the following provinces: on Luzon — Bataan (4), Batangas (5), Bulacan (5), Camarines Norte (1), Mindoro Oriental (2),

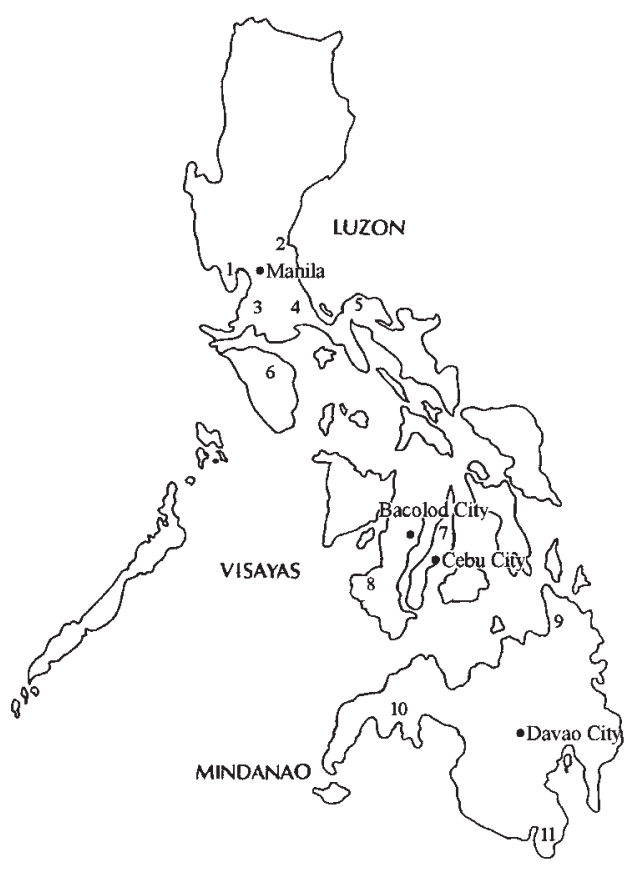

Fig. 1. Map of the Philippines showing the sources of the Penaeus monodon samples collected between January and

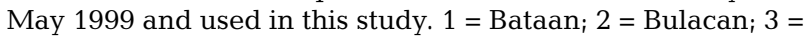
Batangas; 4 = Quezon; 5 = Camarines Norte; 6 = Mindoro Oriental; $7=\mathrm{Cebu}_{;} 8=$ Negros Occidental; $9=$ Agusan del Norte; 10 = Zamboanga del Sur; 11 = Sarangani and Quezon (3); on Visayas — Cebu (17) and Negros Occidental (9); and on Mindanao - Agusan del Norte (11), Sarangani (9) and Zamboanga del Sur (5) (Table 1).

Ten-percent homogenates (in Tris-NaCl-EDTA buffer [TNE]) from whole animals (PL) or from gill tissues of adult shrimp (when hemolymph samples were unavailable) or hemolymph were used as sources of DNA. Prior to DNA extraction, the samples were collected and processed according to the following protocol: about $100 \mu \mathrm{l}$ of either hemolymph or $10 \%$ gill homogenate in TNE (0.05 M Tris, $0.1 \mathrm{M} \mathrm{NaCl}, 0.001 \mathrm{M}$ EDTA, pH 7.4) was collected in microfuge tubes containing $500 \mu \mathrm{l} \mathrm{DNAZol}{ }^{\circledR}$ Reagent (GIBCO Life Technologies). The DNA was extracted according to the manufacturer's protocol.

For PCR amplification, 2 DNA oligonucleotide primers with the following sequences (Tapay et al. 1999) were used: 5' GAA ACT ATT GAA AAG GCT TTC CCT C 3' (forward primer) and 5' GTT CCT TAT TTA CTA CTA CGG CAA 3' (reverse primer). The primers were synthesized by the Biotechnology/Molecular Biology Instrumentation and Training Facility (University of Hawaii, Honolulu, USA). A single PCR reaction mixture containing $1 \times$ PCR buffer, $40 \mu \mathrm{M}$ dNTP mix (Takara Chemicals), $3.0 \mathrm{U} / 100 \mu \mathrm{l}$ DNA polymerase (ULTma Perkin Elmer), $0.2 \mu \mathrm{M}$ Primer 1, $0.2 \mu \mathrm{M}$ Primer 2 , and template DNA $(10 \mu \mathrm{l})$ was prepared for each run. $\mathrm{MgCl}_{2}$ (1.75 mM) was separately added to each reaction tube after the temperature had reached $80^{\circ} \mathrm{C}$. PCR runs were carried out using a Gene Cycler $^{\mathrm{TM}}$ thermal cycler (Bio-Rad Laboratories) for 30 cycles according to the following protocol: denaturing temperature of $95^{\circ} \mathrm{C}$ for $30 \mathrm{~s}$, annealing temperature of $60^{\circ} \mathrm{C}$ for $1 \mathrm{~min}$, elongation temperature of $72^{\circ} \mathrm{C}$ for $30 \mathrm{~s}$, and final extension of $72^{\circ} \mathrm{C}$ for $7 \mathrm{~min}$. A negative control consisting of shrimp DNA or sterile $3 \times$ distilled water and a positive control consisting of WSSV DNA were used as templates and analyzed simultaneously.

For 2-step PCR, the final PCR reaction mixture from samples which tested negative for WSSV after the 1-step PCR protocol were used as DNA templates for a second round of amplification. Conditions for amplification were the same as above.

The PCR amplification products were separated electrophoretically in agarose gel $(2 \%$ in Tris-Borate EDTA buffer, pH 7.6: Tris-base $121.1 \mathrm{~g}, \mathrm{H}_{3} \mathrm{BO}_{3} 55.6 \mathrm{~g}$, NaEDTA $2 \mathrm{H}_{2} \mathrm{O} 3.7 \mathrm{~g}$, distilled water $1 \mathrm{l}$ ) containing ethidium bromide (EtBr, $0.25 \mu \mathrm{g} \mathrm{ml}^{-1}$ ) at $100 \mathrm{~V}$ for about an hour. The EtBr-stained gel was viewed on a Chromatovue Transilluminator ${ }^{\mathrm{TM}}$ and documented using a Mitsubishi Gel Documentation System ${ }^{\mathrm{TM}}$. A positive PCR reaction for WSSV consisted of an amplicon band of $217 \mathrm{bp}$.

For Western blot assays, gill tissue homogenates from adult shrimp or whole animal homogenates for PL were used for analysis according to the method of 
Table 1. Detection of WSSV in adult and post-larvae (PL) of Penaeus monodon from shrimp hatcheries and grow-out farms in the Philippines. na: not applicable

\begin{tabular}{|c|c|c|c|c|c|}
\hline \multirow[t]{3}{*}{ Location } & \multirow{3}{*}{$\begin{array}{c}\text { No. of } \\
\text { samples } \\
\text { collected }\end{array}$} & \multicolumn{3}{|c|}{ No. of samples WSSV-positive } & \multirow{3}{*}{$\begin{array}{l}\text { WSSV }^{\mathrm{d}}- \\
\text { negative }\end{array}$} \\
\hline & & Western & & & \\
\hline & & blot $^{\mathrm{a}}$ & 1-step & 2-step ${ }^{c}$ & \\
\hline Agusan del Norte $\mathrm{e}^{\mathrm{e}}$ & $11^{\mathrm{f}, \mathrm{g}}$ & 0 & 1 & 8 & 2 \\
\hline Bataan & $4^{\mathrm{g}}$ & 1 & 1 & 2 & 1 \\
\hline Batangas & $5^{\mathrm{g}}$ & 0 & 5 & na & 0 \\
\hline Bulacan $^{\mathrm{e}}$ & $5^{\mathrm{h}}$ & 0 & $3^{\mathrm{a}}$ & 0 & 2 \\
\hline Camarines Norte & $1^{\mathrm{i}}$ & 0 & 1 & na & 0 \\
\hline $\mathrm{Cebu}^{\mathrm{e}}$ & $17^{\mathrm{j}}$ & 4 & $7^{\mathrm{k}}$ & $3^{1}$ & 7 \\
\hline Negros Occidental $^{\mathrm{e}}$ & $9^{9}$ & 0 & 5 & 2 & 2 \\
\hline Mindoro Oriental ${ }^{\mathrm{e}}$ & $2^{\mathrm{g}}$ & 1 & $1^{\mathrm{a}}$ & 1 & 0 \\
\hline Quezon & $3^{\mathrm{i}}$ & 0 & 1 & 1 & 1 \\
\hline Sarangani Province & $9^{9}$ & 0 & $6^{\mathrm{a}}$ & 2 & 1 \\
\hline Zamboanga del Sure & $5^{9}$ & 0 & 0 & 1 & 4 \\
\hline Total & 71 & 6 & $31+$ & $=51$ & 20 \\
\hline \multicolumn{6}{|c|}{${ }^{\mathrm{a}}$ Gills of adult shrimp } \\
\hline \multicolumn{6}{|c|}{${ }^{\mathrm{b}}$ Hemolymph of adult shrimp or whole animals for PL, except when otherwise specified } \\
\hline \multicolumn{6}{|c|}{$\begin{array}{l}\text { 'The PCR product from the first step was used as a DNA template for the 2-step PCR. Same PCR reagents and conditions were } \\
\text { followed for both 1-step and 2-step PCR }\end{array}$} \\
\hline \multicolumn{6}{|c|}{${ }^{\mathrm{d} B y}$ either PCR or Western blot analysis } \\
\hline \multicolumn{6}{|c|}{ eWith field cases of mortality } \\
\hline \multirow{2}{*}{\multicolumn{6}{|c|}{$\begin{array}{l}\text { fFry (PL) were obtained from a Cebu hatchery which tested positive for WSSV } \\
\text { gAdult shrimp }\end{array}$}} \\
\hline & & & & & \\
\hline \multicolumn{6}{|l|}{${ }^{\mathrm{h}} 3$ adult and 2 PL } \\
\hline \multicolumn{6}{|l|}{ iPL } \\
\hline \multicolumn{6}{|l|}{ ¡5 adult and $12 \mathrm{PL}$} \\
\hline $\begin{array}{l}{ }^{\mathrm{k}} 2 \text { hemolymph and } 5 \text { PL } \\
{ }^{2} 2 \text { hemolymph and } 1 \mathrm{PL}\end{array}$ & & & & & \\
\hline
\end{tabular}

Nadala et al. (1997). Briefly, PL or fry samples and gill tissues were pooled separately and processed by grinding in TNE buffer (10\% final concentration) using a sterile mortar and pestle. The resulting homogenate was centrifuged at $5000 \mathrm{rpm}\left(1779 \times g_{\text {; }}\right.$ Force 14 Microcentrifuge, Denver Instrument Co.) for $30 \mathrm{~min}$ at $4{ }^{\circ} \mathrm{C}$. The supernatant was collected and further clarified by centrifugation at $3000 \mathrm{rpm}(641 \times g)$ for $30 \mathrm{~min}$. The final supernatant was used for SDS-PAGE according to the method of Laemmli (1970). Briefly, the crude sample preparation was mixed with an equal volume of $2 \times$ loading buffer $(2.5 \mathrm{ml} 0.5 \mathrm{mM}$ Tris- $\mathrm{HCl}, \mathrm{pH} 6.8 ; 4.0 \mathrm{ml}$ $10 \%$ sodium dodecyl sulfate; $2.0 \mathrm{ml}$ glycerol; $1.0 \mathrm{ml}$ $\beta$-mercaptoethanol; and $0.5 \mathrm{ml}$ de-ionized distilled water) heated at $95^{\circ} \mathrm{C}$ for 5 min and centrifuged briefly in a microcentrifuge. Fifteen microliters of each of the test samples was loaded into the wells of a $12.0 \%$ sodium dodecyl sulfate-polyacrylamide gel slab and electrophoresed at $200 \mathrm{~V}$ for 30 to $45 \mathrm{~min}$. The electrophoresed gels were blotted onto nitrocellulose membranes (Schleicher and Schuell, $0.1 \mu \mathrm{m}$ pore size) and used in an immunoassay according to the method of Nadala et al. (1997). The sensitivity and specificity of the hyperimmune polyclonal antibody (IgG) used in this study have been described by Nadala et al. (1997).
Results and discussion. All the samples obtained from farms with field cases (16/16) tested positive for WSSV by PCR (Table 2). A field case refers to a shrimp population reported by farms experiencing mortalities due to unknown causes. Gross manifestations ranged from lack of appetite to reddish discoloration, external fouling and mortality. No macroscopic 'white spots' were visible at the time of sampling. Sixty-two percent of the samples obtained for monitoring purposes tested positive for WSSV (Table 1), although at the time of sampling, the shrimp appeared apparently healthy. It is noteworthy that at least 1 farm in Agusan del Norte

Table 2. Incidence of WSSV in shrimp samples obtained for monitoring purposes and field cases. A field case refers to a shrimp population reported by farms experiencing mortalities due to unknown causes. Gross manifestations ranged from lack of appetite to reddish discoloration, external fouling and mortality. Samples of apparently healthy animals for monitoring purposes were randomly taken from farms/hatcheries in major shrimp-producing provinces of the Philippines

\begin{tabular}{|lcc|}
\hline & No. of samples & WSSV-positive \\
\hline Field case & 16 & 16 \\
Monitoring & 55 & 35 \\
\hline
\end{tabular}


which tested positive for WSSV obtained their PL from a hatchery which also tested positive for WSSV.

Of the total samples (71) tested, 51 (72\%) were found positive for WSSV by PCR assay (Table 2). Thirty-one samples (61\%) were positive after a 1-step PCR (Figs. 2 \& 3) while the remaining 20 samples (39\%) were posi-

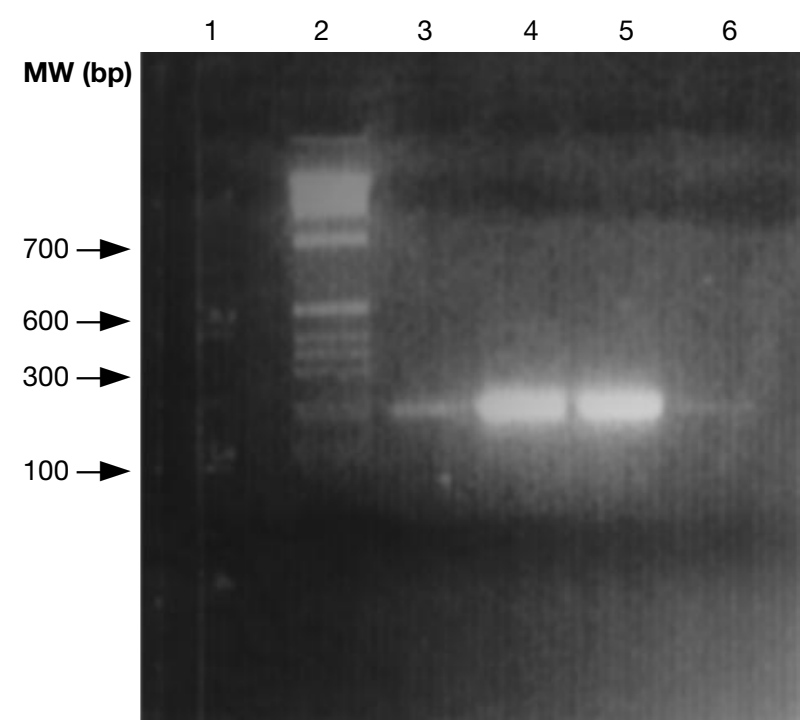

Fig. 2. Electrophoresis gel of PCR products from representative samples with medium to heavy WSSV infections: lane 1, distillled water; lane 2, 1 kb DNA ladder; lane 3, WSSV-positive control; lanes 4 and 5, WSSV-infected ('heavy') samples; and lane 6, WSSV 'light' infection

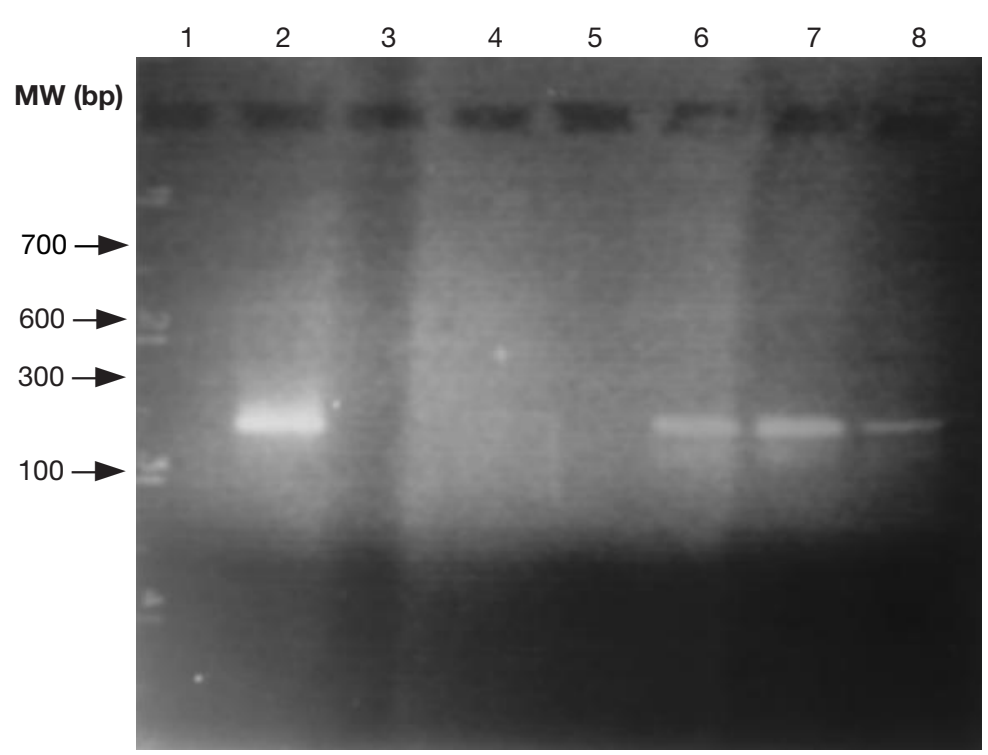

Fig. 3. Electrophoresis gel of PCR products from representative samples with 'light' infection: lane 1, distilled water; lane 2, WSSV-positive control; lanes 3 to 5, PCR products of WSSV-infected samples after a 1-step amplification; and lanes 6 to 8, PCR products of the same samples in lanes 3 to 5 after a 2-step amplification tive only after 2-step PCR. Twenty samples (28\%) were negative for WSSV even after 2-step PCR.

Only 6 samples $(12 \%)$ of the 51 WSSV PCR-positive samples were found positive for WSSV by Western blot assay (Table 1). Fig. 4 shows a representative gel with a band which approximates the prominent non-glycosylated viral envelope component $(27.5 \mathrm{kDa})$ of the WSSV control. The 2 other protein bands (23.5 and $19 \mathrm{kDa}$ ), representing the capsid and envelope components of WSSV, respectively (Nadala et al. 1998), were not observed. It is noteworthy that 2 samples from Cebu which tested positive for WSSV by Western blot assay were found positive by PCR only after a 2-step amplification. The 2 assay samples came from the same animal, although gill tissues were used for the Western blot assay and hemolymph was used for the PCR. All samples that tested negative by PCR assay also tested negative by Western blot assay.

The results of this nationwide screening indicate widespread occurrence of WSSV infection in the Philippines, both in hatcheries $(50 \%$ of the PL samples tested) and in grow-out ponds (79\% of the juvenile/ adult shrimp samples tested). This occurred despite the ban on importation of all morphogenetic stages of Penaeus species (except marketable sizes of 25 to $50 \mathrm{~g}$ ) into the country set by the Department of Agriculture in 1993 through Fisheries Administrative Order 189, Series of 1993. This ban, however, did not prevent the entry of fry through the 'back door' in the south, thereby evading quarantine regulations.

There is currently a fry evaluation procedure being implemented in the Philippines. However, this does not include testing for WSSV. Thus, it is not surprising that PL being stocked in some farms in the country would test positive for WSSV. This was documented in PL samples from some of the hatcheries which were included for monitoring purposes.

Still another possible source of the virus would be the spawners, although a recent study by Belak et al. (1999) revealed that spawners from Palawan, Quezon, Capiz and Negros Occidental provinces tested negative for WSSV by PCR. Their data, however, were limited to 4 sampling sites. Hence, the presence of WSSV in spawners cannot be totally ruled out.

Our most recent samples of wild shrimp from unfiltered sea water pumped into ponds during the cultivation period have tested positive for WSSV by PCR (data not shown). This data strongly suggests that the virus may have been introduced from wild populations of shrimp. 


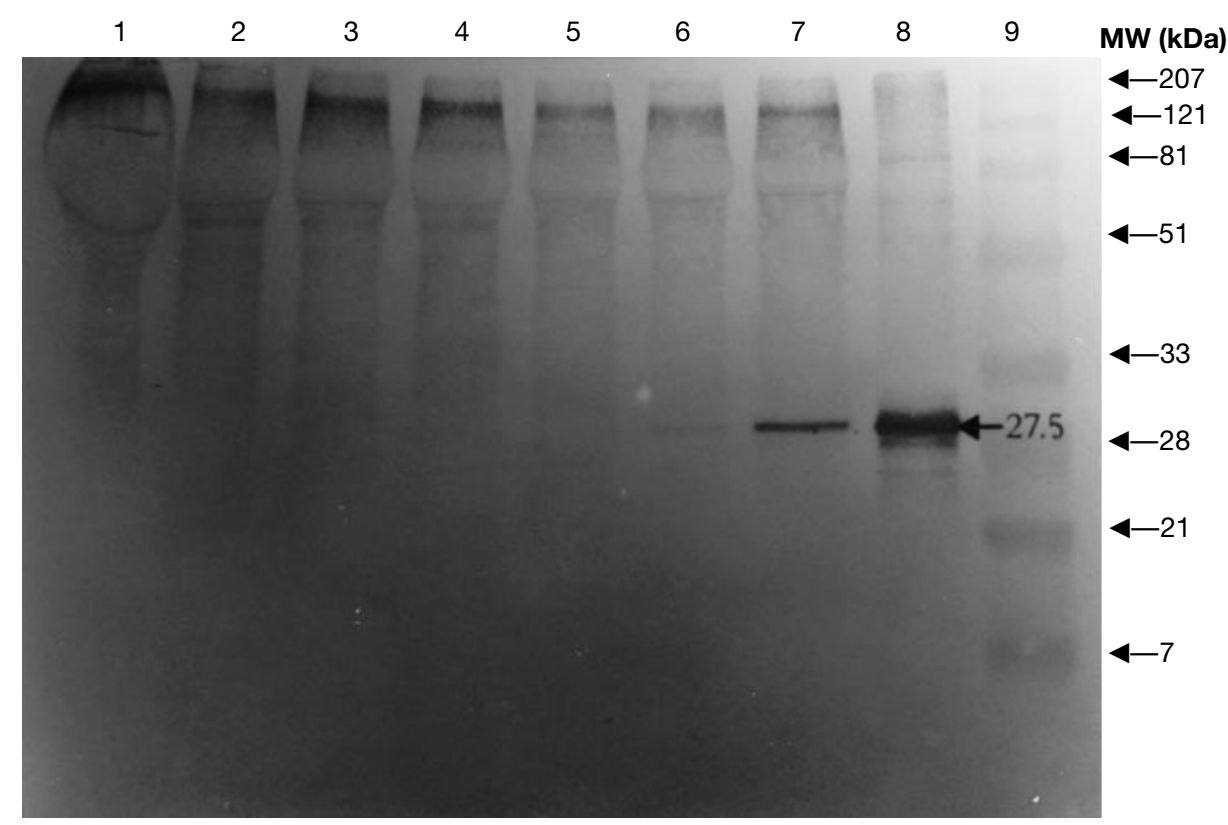

Fig. 4. Western blot analysis of WSSV proteins: lanes 1 to 5, WSSV-negative samples; lanes 6 and 7, WSSV-positive samples; lane 8, WSSV-positive control; and lane 9, prestained broad range molecular weight marker (Bio-Rad Laboratories)

It is noteworthy that, despite the high prevalence of WSSV in the country, no mass mortalities were reported; only loss of appetite, stunted growth and heterogeneous weight sizes (data not shown) were reported from ponds with 'light-grade' infections (e.g. Agusan del Norte samples). This observation may suggest that the infections were at an early stage so that no gross signs of the disease (e.g. 'white spots') were visible. It is also possible that a less virulent, variant strain of the virus was being detected or that the affected shrimp had developed some form of resistance to the virus so that outbreaks of mortality did not occur.

The PCR protocol used in the study was very sensitive. It was capable of distinguishing between light and heavy infections and was more sensitive than the antibody (Ab)-based Western blot assay used. However, despite its lower sensitivity, the Western blot assay proved useful in validating the PCR-positive results obtained from the 'heavily' infected samples (e.g. some samples from Cebu, Bataan and Mindoro Oriental).

Acknowledgements. This study was conducted through a grant from the Philipines' Bureau of Fisheries and Aquatic Resources (BFAR), Department of Agriculture. The authors would also like to acknowledge the shrimp farmers and hatchery operators who provided samples for this study.

\section{LITERATURE CITED}

Albaladejo JD, Tapay LM, Migo VP, Alfafara CG, Somga JR, Mayo SL, Miranda RC, Natividad KT, Magbanua FO,
Itami T, Matsumura M, Nadala ECB Jr, Loh PC (1998) Screening for shrimp viruses in the Philippines. In: Flegel TW (ed) Advances in shrimp biotechnology. BIOTEC, The National Center for Genetic Engineering and Biotechnology, Chiengmai, p 251-253

Belak J, Dhar AK, Primavera JH, de la Peña LD, Pettit P, Alcivar-Warren A (1999) Prevalence of viral diseases (IHHNV and WSSV) in Penaeus monodon from the Philippines and its association with mangrove status and shrimp culture systems. In: Alcivar-Warren A (ed) Proceedings of the Aquaculture and Conservation of Marine Shrimp Biodiversity Symposium. Tufts University School of Veterinary Medicine, North Grafton, MA

Boonyaratpalin S, Supamattaya K, Kasornchandra J, Direkbusarakom S, Aekpanithanpong U, Chantanachookin C (1993) Non-occluded baculo-like virus, the causative agent of yellow head disease in the black tiger shrimp (Penaeus monodon). Fish Pathol 28(3):103-109

Chou HY, Huang CY, Wang CH, Chiang HC, Lo CF (1995) Pathogenicity of a baculovirus infection causing white spot syndrome in cultured penaeid shrimp in Taiwan. Dis Aquat Org 23(3):165-173

Durand S, Lightner DV, Nunan LM, Redman RM, Mari J (1996) Application of gene probes as diagnostic tools for White Spot Baculovirus (WSBV) of penaeid shrimp. Dis Aquat Org 27:58-66

Hameed ASS, Anilkumar M, Stephen Raj ML, Jayaranan K (1998) Studies on the pathogenicity of systemic ectodermal and mesodermal baculovirus and its detection in shrimp by immunological methods. Aquaculture 60:31-45

Kim CK, Kim PK, Sohn SG, Sim DS, Park MA, Heo MS, Lee TH, Lee JD, Jun HK, Jang KL (1998) Development of a polymerase chain reaction (PCR) procedure for the detection of baculovirus associated with white spot syndrome (WSBV) in penaeid shrimp. J Fish Dis 21:11-17

Kimura I, Yamano K, Nakano H, Momoyama K, Hiraoka M, Inouye K (1996) Detection of penaeid rod-shaped DNA Virus (PRDV) by PCR. Fish Pathol 31:93-98 (in Japanese with English abstract) 
Laemmli UK (1970) Cleavage of structural protein during the assembly of the head of bacteriophage T4. Nature 227: 680-685

Lavilla-Pitogo CR, Baticados MCL, Cruz-Lacierda ER, de la Peña LD (1990) Occurrence of luminous bacterial disease of Penaeus monodon larvae in the Philippines. Aquaculture 91:1-14

Lightner DV, Poulos BT, Bruce L, Redman RM, Mari J, Bonami JR (1992) New developments in penaeid virology: application of biotechnology in research and disease diagnosis for shrimp viruses of concern in the Americas. In: Fulks WL, Main KL (eds) Diseases of cultured penaeid shrimp in Asia and the United States. Oceanic Institute, Honolulu, HI

Lo CF, Leu JH, Ho CH, Chen $\mathrm{CH}$, Peng SE, Chen YT, Chou CM, Yeh PY, Huang CJ, Chou HY, Wang CH, Kou GH (1996a) Detection of baculovirus associated with white spot syndrome (WSBV) in penaeid shrimps using polymerase chain reaction. Dis Aquat Org 25:133-141

Lo CF, Ho CH, Peng SE, Chen CH, Hsu HC, Chiu YL, Chang CF, Liu KF, Su MS, Wang CH, Kou GH (1996b) White spot syndrome baculovirus (WSBV) detected in cultured and captured shrimp, crabs and other arthropods. Dis Aquat Org 27:215-225

Lu Y, Tapay LM, Loh PC, Gose RB, Brock JA (1997) The pathogenicity of a baculo-like virus isolated from diseased penaeid shrimp obtained from China for cultured penaeid species in Hawaii. Aquacult Int 5:277-282

Nadala ECB Jr, Tapay LM, Cao S, Loh PC (1997) Detection of yellow-head virus and Chinese baculovirus in penaeid shrimp by Western blot technique. J Virol

Editorial responsibility: Timothy Flegel, Bangkok, Thailand
Methods 69:39-44

Nadala ECB Jr, Tapay LM, Loh PC (1998) Characterization of a non-occluded baculovirus-like agent pathogenic to penaeid shrimp. Dis Aquat Org 33:221-229

Nakano H, Koube H, Umezawa S, Momoyama K, Hiraoka M, Inouye K, Oseko N (1994) Mass mortalities of cultured Kuruma shrimp, Penaeus japonicus, in Japan in 1993. Fish Pathol 29:135-139

Natividad JM (1991) The Penaeus monodon baculovirus (MBV): its epizootiology, prevention and control in penaeid shrimp hatcheries and grow-out ponds in the Philippines. PhD dissertation, School of Renewable Resources, University of Arizona, Tucson

Tapay LM, Nadala ECB Jr, Loh PC (1999) A polymerase chain reaction (PCR) protocol for the detection of various geographical isolates of White Spot Virus (WSV). J Virol Methods 82:39-43

Wang CH, Lo CF, Leu JH, Chou CM, Yeh PY, Chou HY, Tung MC, Chang CF, Su MS, Kou GH (1995) Purification and genomic analysis of baculovirus associated with white spot syndrome (WSBV) of Penaeus monodon. Dis Aquat Org 23(3):239-242

Wang CS, Tsai YJ, Kou GH, Chen SN (1997) White spot disease virus infection in wild-caught greasy back shrimp, Metapenaeus ensis (de Haan) in Taiwan. Fish Pathol 32: $35-41$

Wongteerasupaya C, Sriurairatana S, Vickers JE, Akrajamon A, Boonsaeng V, Panyim S, Tassanakajon A, Wichayachumnarnkul B, Flegel TW (1995) Yellow-head virus of Penaeus monodon is an RNA virus. Dis Aquat Org 21: $69-72$

Submitted: September 22, 1999; Accepted: March 19, 2000 Proofs received from author(s): June 19, 2000 